\title{
Is there a Relation between CEO Remuneration and Banks' Size and Performance?
}

\author{
Dr. Imad Kutum \\ Independent Researcher \\ Kutum \& Associates Inc. \\ 200-5660 McAdam Road \\ Mississauga, Ontario L4Z 1T2, Canada \\ Tel: 1-905-330-6826_～Email: imad@kutum.com
}

Accepted: May 25, 2015

DOI: 10.5296/ijafr.v5i1.7653 URL: http://dx.doi.org/10.5296/ ijafr.v5i1.7653

\begin{abstract}
The goal of the study is to establish what kind of relationship, if any, exists between CEO remuneration and Banks size and performance. The study is extremely relevant, especially in the financial sector after the crisis of 2007-2008. Many critics have argued both as rhetoric as well as an empirical study that high executive pays have a negative impact on the sustainability and success of a firm. Studying the literature reveals plurality in positions. Since this is an extremely complex question, it is understandable that literature exists arguing on both sides of the debate. This paper collected data on Bank Size and Bank Performance for 6 Canadian banks to study their correlation with CEO remuneration. It was hypothesized that there existed a positive relationship between CEO remuneration and Bank Size (measured by Sales, Deposits and Employees) and Bank Performance (measured by ROA, ROE and Profit Margin). The data was put through SPSS for a Pearson coefficient analysis which revealed a strongly positive correlation between CEO remuneration and all three variables of Bank Size. On the other hand, no significant relationship could be established between CEO remuneration and Bank Performance except a weak positive relationship with ROA. The study can be helpful in executive decision making. However, it also calls for further research into external factors that have an impact on the relationships between these variables. Most importantly a comparison study following the same methodology of different regions can give us more useful business intelligence and insight.
\end{abstract}

Keywords: CEO Remuneration, Canadian Banks, Performance, Size 


\section{Introduction}

Executive compensation, both financial and non-financial, have been under the microscope of research institutes and think tanks, especially after the recent economic crisis and the activism that followed that called for lessening CEO compensation including the amount of money paid. The goal of the study is to establish what kind of relationship exists between CEO remuneration and Banks size and performance. Economic theory of executive pay in the academic world has tried to suggest an optimal design that aligns the interests of managers/executives with those of shareholders and wider stakeholders. The financial crisis of 2007-2008 has re-ignited the debate, especially in the banking sector which makes this study all the more relevant. Executive and CEO compensation in financial institutions has specially been under investigation within the context of 'shareholder oversight efficiency' (Yang, Dolar\& Mo, 2014). Critics claim that executive compensation should be re-visited for a wide variety fo reasons including perverse incentives for reckless management and irresponsible risk taking decisions (Yang, Dolar\& Mo, 2014). The president of USA announced a cap of \$500,000 for top executives that were the highest recipients of the bailout program (Jeppson, Smith \& Stone, 2009, p. 81). This was justified as common sense. This paper reviews through primary and secondary research the validity of this claim through empirical research rather than just common sense.

\section{Literature Review}

Matolcsy\& Wright (2011) conducted a study to investigate the relationship between compensation of CEO and performance of firm. The study examined the model of effective structure of compensation depending on characteristics of firm and then tested the performance outcomes of shift from the efficient structure of compensation. The results of the study were dependent on 3503 companies for the time period of 1999 to 2005. The findings of the research showed that organization in which CEOs get the compensation uneven with the characteristics of firm has lower level of performance in comparison with the firms in which the compensation of CEO is consistent with the characteristics such as size of firm. The study used both accounting as well as market dependent measures of performance. As a whole, this study gives some significant new insights due to which compensation of CEO is linked with performance of firm. The investigation takes the variable such as firm size and concludes that the CEO compensation must be consistent with this variable for higher performance.

Berry et al (2009) conducted a research for analyzing the relationship between compensation of CEO and performance of firm. The study used sample consisting of 917 manufacturing companies of US for the time period of 1992-2003. They used wealth indicator as metric for compensation of CEO which helps in measuring the change in wealth of CEO. The effect of volatility in stock price on behavior of CEO is measured by a tool called BSY. The dependent variable was performance of firm which was taken through measurement of comparative productivity of every organization with its competitors in that specific industry. BSY also helps in measuring the comparative financial performance of companies through the use of Tobin's Q metric. According to the study an increase in wealth of CEO to \$2.3 million, the performance of firm is also enhanced. It has also been found that due to increase in capital ownership the wealth of CEO has been roused and the financial performance of firm reduced. 


\section{Mll Macrothink}

International Journal of Accounting and Financial Reporting ISSN 2162-3082 2015, Vol. 5, No. 1

Mobbs (2013) argued that directors inside the firm for whom there is high level of demand due to their skills in the market, as shown by their holdings external to the directorships, have more chances of becoming CEOs. He concluded their existence is linked with more forced sensitivity of CEO towards turnover to accounting outcomes and compensation reaction of CEO to performance of stock. These findings have revealed that some insiders make the monitoring of board strong through serving as a voluntarily available replacement of CEO and this is in contrast with the assumption that CEO has an authority of controlling all the insiders. Moreover, the findings remain consistent at the time of considering the endogenous selection of companies of skillful and competent directors who are present inside the firm.

Lin et al (2013) wanted to empirically the test the grounds of executive pay and also examined the phenomenon of fat cat. Fat cats are those with high compensation and the power to increase their own salaries (Lin et al, 2013). The researchers also tried to analyze those firms as sample in which there is a problem of fat cat i.e. companies with poor performance outcomes and high CEO compensation. The sample was of 903 firms of US and it has been found that there is a exchanging effect between compensation of CEO and the level of ownership of CEO and bigger organizations give more pay to their CEOs. As the sample size of this research was limited to only fat cat firms, it has been found that tenure and size of firm have significant positive impact on compensation of CEO. The size of firm, leverage ratio and opportunities for investment have significant relationship with total compensation of CEO (research is limited to fat cat firms in the banking sector). As a whole, the findings of the study have revealed that the size of firm is the most important factor in determining the compensation of CEO and there is usually lack of link between pay and performance outcome.

"Most companies are characterized by the separation of ownership and control where the ownership is held by diverse shareholders and the control lies in the hands of top executives. As a result, shareholders are not able to monitor managers' actions directly. According to the agency theory, these companies are likely to suffer from agency problems. That is, managers as the agents may not always act in the interest of the shareholders (i.e., the principals), thereby giving rise to conflicts of interests. (Lin et al, 2013, Pg. 2).

Guthrie et al (2012) investigated CEO Compensation and Board Structure. They estimated that there is $17 \%$ decrement in the pays of CEO in firms that are not suitable with the current NYSE/ Nasdaq board independence need than as compared to the compliance in firms. The document stated that total of $74 \%$ is attributable to about two outliners from sample of 865 firms. Moreover, it was also noticed that compensation committee independence requirement enhances the total pay of CEO, especially in the existence of effective monitoring of shareholder. The evidence casts have a doubt on the efficiency of independent directors in order to constrain the CEO pay as stated by the managerial power hypothesis.

Yang et al (2014) found that financial compensation of the officer in the index of effectiveness of oversight of shareholder and control has been seen as the most frequently occurring problem for so many decades in the corporate environment of U.S. it has been observed that at the time of financial crisis in U.S in the year 2007-2008, enhanced executive compensation transformed into a main point of criticism. The research observes the influence of the current financial crisis on the link between performance of firm and CEO 


\section{MInstitute Macrothink $_{\text {Int }}$}

International Journal of Accounting and Financial Reporting ISSN 2162-3082 2015, Vol. 5, No. 1

compensation, and observes that if the crisis altered their relationships or not between the two components. With the help of the Standard database, it has been concluded that the link between firm performance and CEO compensation depicts different types of patterns in the pre and post crisis periods.

Jeppson, Smith \& Stone (2009) observed the link between difference aspects of firm performance and CEO compensation across different industries. The research used a CEO compensation database for 200 broad public organizations which set proxy statements along with the SEC for the year 2007. Sum of the CEO compensation involves: option awards, stock awards, perks, cash bonuses and base salary. Some of the measures regarding the firm performance were: year-to-year alteration in net income, revenue of the company, and year-to-year change in total shareholder return (TSR). Regression and correlation analysis were used in order to test different hypothesis. It was expected that CEO compensation and its factor have direct relation with the financial measures of the performance of the company.

Murphy \&Zabojnik (2004) commented on the belief that current increment in pay reflects the increment in power that self-dealing CEOs wield over different captive boards. This enhanced the power and permits the CEOs to get more rents from their organizations, at the cost of the organization's shareholders and workers. The arguments regarding the "rent-extraction" description must be critically examined specially in context of market based definition of current trends. Increment in executive compensation can be defined by the increment in the significance of general skills, opposite to firm-particular knowledge, to manage the advance corporations.

Nourayi firth\&Mintz (2008) claimed that "CEO compensation and Tenure, Firm's Performance" effected CEO cash, firm performance and total compensation depending upon the time. The size of the firm seems to be an important explanatory variable for total compensation and CEO cash regardless of performance measure and CEO tenure. The data was being used for the year 2001-2002.

Ozkan (2011) observed the relation between CEO performance and pay employing a special, hand collected panel data set of 390 UK non-financial firms from the FTSE All Share Index for the year 1999-2005. Both of the cash salary and cash bonus were included and they were based on equity (long term incentive plans and stock options) factors of CEO compensation, and wealth of CEO based on the share holdings, stock awards holdings and stock option in the analysis. Moreover, there was control on the comprehensive set of governance variables. The conclusions proved that as compared to the last findings for US CEOs, pay-performance elasticity for UK CEOs is 0.075 (0.095) for total direct compensation and pay performance elasticity for UK CEOs tends to be lower, identifying that there is an increment of 10 percent. The stock-based pay performance and median share holdings are lower for UK CEOs when the findings are compared with the previous findings for US CEOs.

Thus according to conclusions the corporate governance reports for instance Greenbury Report (1995) that stated that CEO compensation be more closely attached to performance, is not entirely effective. The findings also concluded that organizational ownership has a positive and important impact on CEO pay performance sensitivity of choice grants. Then in the end, it has been found that longer CEO tenure is linked with the lower pay-performance 
sensitivity of choice grants which gives the suggestions of the entrenchment effect of tenure of CEO.

Gregg et al. (2005) observed the link between cash compensation and performance of the company for a model of broad UK organizations over the year 1994-2002. Their results proved that there is some relationship between performance and cash compensation.

Michaud \&Gai (2009) gives empirical validation of the theoretical links between the CEO compensation and firm performance. The rational behavior hypothesis is known as "CEO which is get more paid works harder and then succeed and improve the financial performance of the organization she/he leads. In order to test the relationship as hypothesis, the information was collected from the firms and CEO compensation from the EXECUCOMP and COMPUSTAT data bases. Of the SP500 firms, only 276 firms were selected which had complete data in the year 1995 to 2004 in 10 year period. It has been estimated that there are three indicators/measures of the performance of the firm: Economic Value Added (EVA), Return On Equity Average (ROE_AVG), and Return on Equity (ROE). CEO compensation is measured with the help of six categories: Total CEO Compensation, Long Term Incentive Payouts (LTIP), Options Awarded, Restricted Stock Grants, and CEO Salary. There were more than 40000 observations related to compensation of both CEOs and profit returns of the corporate in the significant large organizations during the time period when media, analysts and research community of university made a call for CEOs for getting with it. After taking control on fixed impacts like macroeconomics and particular conditions of industry of all the six kinds of compensations of CEO, the researcher found that there is only significant effect of cash bonus on performance of firm. When the cash bonus is increased by one million dollar which means increase by $83.68 \%$ then due to this the average ROE is increase by $1.15 \%$ in the model of fixed effects or in case of model of random effects, it would be $1.03 \%$. However, once control is taken on endogeneity of compensation of CEO i.e. it is simultaneously linked with performance of overall firm, there is no significant impact of any of the six types of payments on performance of firm. It has been suggested by the findings of the research that there must be rethinking on the role of compensation of CEO taken in the form on incentive to improve performance of firm i.e. can the annual profits of organization can really be affected by CEO.

Firth et al (2005) conducted a research examining the CEOs compensation in listed companies of China. The paper goes into the context of CEO compensation and then discusses the factors that explain the changes in the usage of pay related to performance. In China, there is dominancy with the listed companies in case of having control on the shareholders and the researchers have argued that the unique kinds to control shareholder have various effects on the utilization of incentives. It has been found that in companies in which the State agency is considered as the main shareholder are not interested in using pay related to the performance. In contrary to this, companies in which there are private block holders or SOEs as main shareholders are related with the increase in pay of CEOs in wealth of shareholders or enhancement in profitability. However, the sensitivity between pay and performance in case of CEOs is low and due to this the effectiveness of incentive system of firms are questioned.

"One significant difference between listed firms in China and those in other countries is the 
ownership of shares. Most listed firms have a dominant shareholder that helps shape the strategies and policies of the company. The dominant shareholder can exercise substantial control over a firm by way of board representation as well as through voting rights"(Firth et al, 2006; Pg. 2).

Wallsten (2000) tried to find a statistical linkage between compensation of executives and performance. He studied two different features of association. First he tried to find the change in relationship based on performance of firm and secondly he found the change in relationship due to rank of executives in the company. He found that in case of relationship with firm, company gives higher rewards to its executives during the good time period but they do not punish them in bad time period or during poor performance of company. In case of relationship with rank of executives, he found that there is strong relationship between compensation of top executive with performance, less in case of second highest executive and so on.

Gabay\&Ruge-Murcia (2005) examined the relationship between performance of firm and compensation of CEO in Canada. The sample size of the study was 168 Canadian firms for the year 2003 and they firstly considered the wide cluster of industry sectors. This research focuses on analyzing previous researchers and found a positive relationship between salary and firm's performance. This research is different from others in a way that it has found a high level of sensitivity among salary of CEO and performance of company. The findings of the study are true in case of different structures of compensations and in relative to four different measures of performance. In addition to this, they also tried to differentiate the case that focuses on change in level of sensitivity among wage and performance of company when concentrating on particular markets, same tests were used for a subgroup in which raw material, products related to industry and public service sectors were involved. While, they found still positive relationship between salary and performance of firm, the wage's coefficients were lesser which depicted that they have less responsiveness towards performance.

Aduda (2011) examined the relationship between compensation of executive and performance of firms in commercial banks which are listed at the Nairobi Stock Exchange. The research has focused on functional type relationship between level of remuneration of executive and measures of performance with the use of regression model which is related to pay and performance. The research findings suggested that measures of performance are not the most important considerations to determine compensation of executive in the larger commercial banks of Kenya and their size is considered to be important criteria to determine compensation of executive because there was significant negative relation between size and compensation Yermack (2004). The negative relationship depicted to cap the compensation of executive for ensuring that returns to shareholders are maximized.

Doucouliagos et al (2006) examined the relationship between pay of directors and CEOs with performance in Banks of Australia. They used sample of banks for the time period 1992-2005. The findings have shown that there is absence of simultaneous link between pay of directors and performance of firms and there was no relationship found in performance of previous years. 


\section{Mll Macrothink}

International Journal of Accounting and Financial Reporting ISSN 2162-3082 2015, Vol. 5, No. 1

Cao \& Wang (2013) conducted a research for integrating an agency problem with the search theory for exploring the compensation of executive at the time of equilibrium in market. It has been found that a CEO can stay quiet and look after through individual observation of an idiosyncratic collapse in the firm. The researchers found that there is lower value of optimal pay to performance ratio as compared to that one when the risk of CEO is neutral.

The to-the-point nature of the payment changes greatly in the companies and may involve not only financial income just before or after the supply of labor (Muriithi, 2004) but also include deferred payments like pensions and pay for holiday (Core \&Larcker, 2002), along with non-monetary rewards like health insurance and other related benefits (Dale-Olsen, 2006).

There is high level of correlation between well-being of workers and assumptions of their salary in relative to their sub-ordinates (Brown et al., 2003). Natarajan (1996) explored the role of factors of earnings in compensation contracts of CEO. He argued that shareholders will utilize those components of earnings like additional measures of performance whenever the aspects give information more than the earnings related to decisions of management (Askary\&Doucouliagos, 2005). Stapledon argued that the CEO of company captures the board of directors with different board and social dynamics of board which de-motivated the non-executive directors from demanding increment (Stapledon, 2004).

\section{Methodology}

\subsection{Data Collection}

For the purposes of our investigation, data has been collected from 6 Canadian Banks (Royal Bank of Canada, The Bank of Nova Scotia, Toronto-Dominion Bank, Canadian Imperial Bank of Commerce, Bank of Montreal, and National Bank of Canada). The data taken is from the years 2010 to 2014 and obtained from official resources such as the annual reports and official publications.

\subsection{Variables}

The central investigation of the paper deals with CEO pay with Bank size and Bank performance. Following illustration explains the way bank size and bank performances are broken down. Return on Assets is an indicator of how profitable a company is relative to its total assets. Return on Equity is the amount of net income returned as a percentage of shareholders equity.Return on Assets will be referred to as ROA while Return on Equity will be referred as ROE.
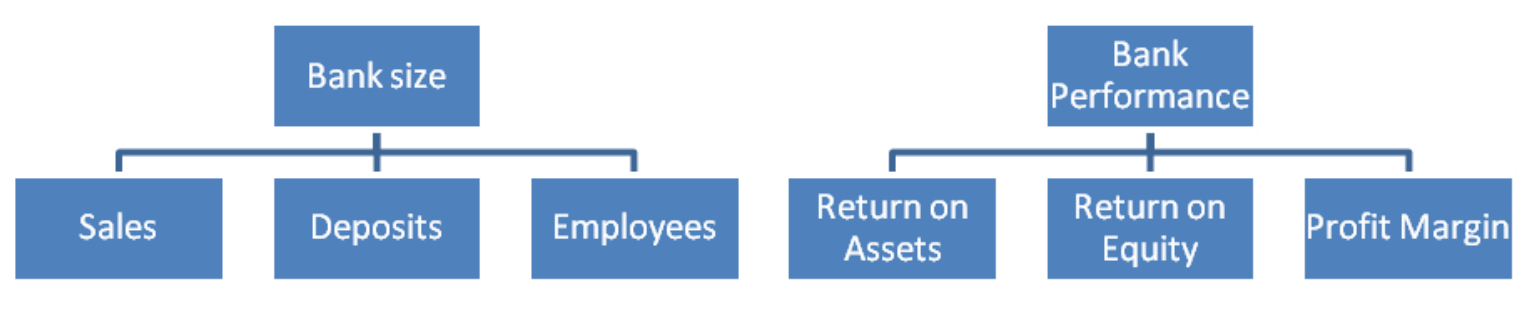

The research uses a mix of secondary research and primary research. For the purposes of secondary research around 25 peer-reviewed papers were studied. The primary research is quantitative and evaluates the six variables seen in the above illustration. The research 


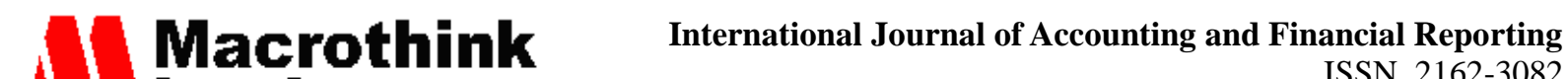

investigated the validity of the following hypotheses.

H1: There is a positive relationship between CEO pay and Gross Sales

H2: There is a positive relationship between CEO pay and Customer Deposits

H3: There is a positive relationship between CEO pay and Number of Employees

H4: There is a positive relationship between CEO pay and Profit Margin

H5: There is a positive relationship between CEO pay and ROA

H6: There is a positive relationship between CEO pay and ROE

\subsection{Tools and Measurement}

SPSS was used as the statistical analysis software. For the purposes of investigating the correlation in the six hypotheses the Pearson's correlation is used. This is also known as correlation coefficient. Pearson correlation coefficient is defined as the covariance between two different variables divided by the multiplication of their standard deviations. The Pearson correlation method is used for measuring the strength and movement direction of the relationship between two variables i.e. independent and dependent variable on one interval scale (Anderson, 1996).

Pearson correlation is very useful inthis types of studies in which there is a need of finding relationship between two different variables. One variable must be independent and other must be dependent variable. This method is useful in finding the impact of one variable on other. In this research Person Correlation is very helpful because we want to find the relationship between CEO compensation and firm's performance and size. The value of Pearson correlation is very important in analyzing that with how much percentage an independent variable has an impact on dependent variable. The value of Pearson correlation can be in between +1 to -1 . As the value moves to 1 , it shows that there is strong relationship between both independent and dependent variable. This shows that variation in one variable in strongly correlated with changes in other variable. If the value is negative there is a negative correlation while a value around 0 shows no relationship (Pearson, 1900). This method of correlation is helpful in current study because it can help us identify the direction and value of relationship between performance and size of banks with compensation of CEOs. 
4. Results and Analysis

H1: There is a positive relationship between CEO pay and Gross Sales

\begin{tabular}{|llrr|}
\hline & & Correlations & Gross Sales \\
CEO Pay & CEO Pay & $.774^{* *}$ \\
& Correlation & 1 & .000 \\
& Sig. (2-tailed) & & 24 \\
N & & 24 & 1 \\
& Pearson & .774 & \\
& Correlation & & 24 \\
& Sig. (2-tailed) & .000 & \\
& N & 24 & \\
& & & \\
& & &
\end{tabular}

The correlation is $\mathbf{0 . 7 7 4}$. Correlation that is higher than 0.5 is considered significant. The correlation is significant therefore we can conclude that there is exists a strong positive relationship between CEO pay and Gross Sales.

H2: There is a positive relationship between CEO pay and Customer Deposits

\begin{tabular}{|llrr|}
\hline \multicolumn{2}{c}{ Correlations } & \\
CEO Pay & CEO Pay & Customer Deposits \\
& Pearson & & $.806^{* *}$ \\
& Correlation & & .000 \\
& Sig. (2-tailed) & & 24 \\
Customer Deposits & Pearson & 24 & 1 \\
& Correlation & $.806^{* * *}$ & \\
& Sig. (2-tailed) & & 24 \\
& $\mathrm{~N}$ & .000 & \\
\hline
\end{tabular}

The correlation is $\mathbf{0 . 8 0 6}$ which is extremely significant therefore we can conclude that there is exists a strong positive relationship between CEO pay and Customer Deposits. 
H3: There is a positive relationship between CEO pay and Number of Employees

\begin{tabular}{|c|c|c|c|}
\hline \multicolumn{4}{|c|}{ Correlations } \\
\hline & & CEO Pay & Number of Employees \\
\hline \multirow[t]{4}{*}{ CEO Pay } & Pearson & 1 & $.789^{* *}$ \\
\hline & Correlation & & \\
\hline & Sig. (2-tailed) & & .000 \\
\hline & $\mathrm{N}$ & 24 & 24 \\
\hline \multirow{4}{*}{$\begin{array}{l}\text { Number } \\
\text { Employees }\end{array}$} & Pearson & $.789^{* *}$ & 1 \\
\hline & Correlation & & \\
\hline & Sig. (2-tailed) & .000 & \\
\hline & $\mathrm{N}$ & 24 & 24 \\
\hline
\end{tabular}

The correlation is $\mathbf{0 . 7 8 9}$ which is high. We can conclude that there is exists a strong positive relationship between CEO pay and Number of Employees.

H4: There is a positive relationship between CEO pay and Profit Margin

\begin{tabular}{|llrr|}
\hline \multirow{5}{*}{ CEO Pay } & & Correlations & Profit Margin \\
& Pearson & CEO Pay & -.017 \\
& Correlation & 1 & \\
& Sig. (2-tailed) & & .936 \\
& N & 24 & 24 \\
Profit Margin & Pearson & -.017 & 1 \\
& Correlation & & \\
& Sig. (2-tailed) & .936 & 24 \\
& N & 24 & \\
\hline
\end{tabular}

The correlation is -.017. While being negative it is extremely low and insignificant. Had it been at lesser than -0.1 , we could have established a negative correlation. There exists no significant relationship between CEO pay and Profit Margin. 
H5: There is a positive relationship between CEO pay and ROA

\section{Correlations}

\begin{tabular}{|l|l|l|l|}
\hline \multicolumn{2}{|l|}{} & CEO Pay & ROA \\
\hline \multirow{2}{*}{ CEO Pay } & $\begin{array}{l}\text { Pearson } \\
\text { Correlation }\end{array}$ & 1 & .267 \\
\cline { 2 - 4 } & Sig. (2-tailed) & & .208 \\
\cline { 2 - 5 } & N & 24 & 24 \\
\hline \multirow{2}{*}{ ROA } & $\begin{array}{l}\text { Pearson } \\
\text { Correlation }\end{array}$ & .267 & 1 \\
\cline { 2 - 5 } & Sig. (2-tailed) & .208 & 27 \\
\cline { 2 - 4 } & N & 24 & \\
\hline
\end{tabular}

The correlation is $\mathbf{0 . 2 6 7}$ which is medium. We can conclude that there is exists a moderate positive relationship between CEO pay andROA.

H6: There is a positive relationship between CEO pay and ROE

\section{Correlations}

\begin{tabular}{|l|l|l|l|}
\hline \multicolumn{2}{|l|}{} & CEO Pay & ROE \\
\hline \multirow{2}{*}{ CEO Pay } & $\begin{array}{l}\text { Pearson } \\
\text { Correlation }\end{array}$ & 1 & -.093 \\
\cline { 2 - 5 } & Sig. (2-tailed) & & .666 \\
\cline { 2 - 5 } & N & 24 & 24 \\
\hline \multirow{2}{*}{ ROE } & $\begin{array}{l}\text { Pearson } \\
\text { Correlation }\end{array}$ & -.093 & 1 \\
\cline { 2 - 5 } & Sig. (2-tailed) & .666 & 27 \\
\cline { 2 - 5 } & N & 24 & \\
\hline
\end{tabular}

The correlation is $\mathbf{- . 0 9}$. While being negative it is extremely low and insignificant. Had it been at lesser than -0.1 , we could have established a negative correlation. There exists no significant relationship between CEO pay and ROE. 


\begin{tabular}{|l|l|}
\hline Hypothesis & Validity \\
\hline $\begin{array}{l}\text { H1: There is a positive relationship between } \\
\text { CEO pay and Gross Sales }\end{array}$ & True - strong positive \\
\hline $\begin{array}{l}\text { H2: There is a positive relationship between } \\
\text { CEO pay and Customer Deposits }\end{array}$ & True - strong positive \\
\hline $\begin{array}{l}\text { H3: There is a positive relationship between } \\
\text { CEO pay and Number of Employees }\end{array}$ & True - strong positive \\
\hline $\begin{array}{l}\text { H4: There is a positive relationship between } \\
\text { CEO pay and Profit Margin }\end{array}$ & False - no correlation found \\
\hline $\begin{array}{l}\text { H5: There is a positive relationship between } \\
\text { CEO pay and ROA }\end{array}$ & True - medium positive \\
\hline $\begin{array}{l}\text { H6: There is a positive relationship between } \\
\text { CEO pay and ROE }\end{array}$ & False - no correlation found \\
\hline
\end{tabular}

Bank Size: The three hypotheses that dealt with Bank size were H1, H2 and H3. All three have been found to be strongly positively correlated. This means we can clearly establish that there is a strong positive relationship between CEO compensation and Bank size

Bank Performance: The three hypotheses that dealt with Bank size were H4, H5 and H6. H4 and $\mathrm{H} 6$ were not proven while $\mathrm{H} 5$ established a medium positive correlation. This means we cannot establish a strong positive relationship between CEO compensation and Bank Performance. A weak relationship may be established based on the variable of return on assets. However, based on return on equity and profit margin there exists no significant correlation.

\section{Conclusion}

Three important lessons can be taken away from this research. First and foremost, this original primary research re-enforces a lot of academic work done before (as reviewed in the literature) as far as bank size and CEO pay is concerned. The strongest and significantly positive relationship can be seen between CEO pay and profit margin. A correlation coefficient of more than 9 is extremely strong. Both customer deposits and number of employees are also strongly positive. These three hypotheses can act as criteria for decision making of setting executive salaries. In the post economic-crisis world, it also dismisses the notion that higher executive salaries may negatively impact the profit margin of a bank.

Secondly, the research isn't able to successfully establish a relationship between executive pay and bank performance. While two of the correlations were negative but being so close to zero, they are seen as insignificant. However, a moderate positive relationship between ROA and CEO pay is encouraging. As a net effect, one may argue that there exists a weak positive relationship between executive pay and bank success. However, executive pay increments cannot be justified merely on the basis of possible bank performance in Canada.

Thirdly, the research points towards further questions to be explored. On one hand we have 
established a strong positive relationship between CEO pay and Bank size. This calls for a study of bank size and bank performance, deconstructing them further. It may even be enlightening to compare these findings, especially that of performance, with other regions. Other bank performance indicators might also be studied as well as a review of how the external market effects any relationship between size and performance.

\section{References}

Aduda, J. (2011). The relationship between executive compensation and firm performance in the Kenyan banking sector.Journal of Accounting and Taxation.Vol. 3(6), pp. 130-139

Anderson T.W., (1996).R.A. Fisher and multivariate analysis. Statistical Science 11 (1): $20-34$

AskaryS,\&Doucouliagos H (2005). "Directors' Remuneration and Performance in the Austrailian Banking Sector," Working paper,Deakin University - School of Accounting, Economics and Finance. Finance

Berry, T. K., Fields, L. P. \&Wilkins, M. S., 2006.'The interaction among multiple governance mechanisms in young newly public firms', Journal of Corporate Finance, pp. 449-66.

Brown MP, SturmanMC ,\& Simmers MJ (2003).“Compensation Policy and Organizational Performance: The Efficiency, Operational and Financial Implications of Pay Levels and Pay Structure". Academy of Management.Journal., 46: 752-762

Cao, M.,\& Wang, R., (2013).Optimal CEO Compensation with Search: Theory and Empirical Evidence. The Journal of Finance.LXVIII( 5)

Core J, Larcker D (2002). "Performance Consequences of Mandatory Increases in Executive Stock Ownership'. J. Financial Econ., 64: 317- 340

Dale-Olsen H (2006). "Wages, Fringe Benefits and Worker Turnover", Labour Economics, 13 (1): 87-105.

Doucouliagos, H., Askary, S.,\& Haman, J. (2006). "Directors' Remuneration and Performance in Australian Banking" School Working Paper

Gabay, D.E.,\&Ruge-Murcia, F., (2005).Firms Performance and CEO Compensation in Canada.Université de Montréal

Greenbury, S.R. (1995). 'Directors' Remuneration', London: Gee \& Co. Ltd.

Gregg, P., Jewell, S. \&Tonks, I., (2005) 'Executive pay and performance in the UK 1994-2002', Working Paper (XFi Centre for Finance and Investment)

Jeppson. T, .Smith, W., \& Stone, R. (2009). CEO Compensation and Firm Performance: Is there any Relationship? Journal of Business \& Economics Research.7, 81-94.

Firth, M., Fung, P.M.Y, \&Rui, M.O. (2006).Corporate Performance and CEO Compensation in China.Journal of Corporate Finance, 12. 693- 714

Guthrie, J., Sokolowsky, J., \&Wan, K..(2012). CEO Compensation and Board Structure Revisited.The Journal of Finance.LXVII (1149.

Lin,D., Kuo, H.C., \&Wang, L.H. (2013). Chief Executive Compensation: An Empirical Study of Fat Cat CEOs. The International Journal of Business and Finance Research, 7(2). 


\section{Macrothink}

International Journal of Accounting and Financial Reporting ISSN 2162-3082 2015, Vol. 5, No. 1

Matolcsy, Z., \&Wright, A. (2011).CEO Compensation Structure and Firm Performance.Accounting and Finance 51, 745-763

Michaud, D.W \&Gai, Y. (2009).CEO Compensation and Firm Performance. Electronic copy available at: http://ssrn.com/abstract $=1531673$

Mobbs, S. (2013). CEOs Under Fire: The Effects of Competition from Inside Directors on Forced CEO Turnover and CEO Compensation. Journal of Financial and Quantitative Analysis.48(3) 669-698

Murphy, K.J. \& J. Zabojnik (2004), "CEO Pay and Appointments: A Market-Based Explanation for Recent Trends",The American Economic Review. Vol. 94, Iss. 2, 192-196

Muriithi AK (2004). "The Relationship Between Corporate Governance Mechanism and Performance of Firms Quoted at the Nairobi Stock Exchange' [unpublished]

Natarajan R (1996). "Stewardship Value of Earnings Components: Additional Evidence on the Determinants of Executive Compensation", Accounting Review, 71(1): 1-22.

Nourayi, M.\&Mintz, S (2008), “Tenure, Firm's Performance, and CEO's Compensation," Managerial Finance, 34(8), p.524

Ozkan, N. (2011). CEO Compensation and Firm Performance: An Empirical Investigation of UK Panel Data. European Financial Management, 17(2), 260-285

Pearson K., (1900). Mathematical contributions to the theory of evolution. VII. On the correlation of characters not quantitatively measurable. Philosophical Transactions of the Royal Society Ser. A 195: 1-47.

Stapledon G (2004). "The Pay for Performance Dilemma", University ofMelbourne Legal Studies Research Paper No. 83.

Wallsten, S.J., (2000). Executive Compensation and Firm Performance: Big Carrot, Small Stick. Stanford Institute for Economic Policy Research, Discussion Paper, 99-017

Yang.F., \&Dolar. B., Mo, L. (2014). CEO Compensation and Firm Performance: Did the 2007-2008 Financial Crisis Matter? Journal of Accounting and Finance.14(1), 137-146

Yermack, D. (2004). "Remuneration, Retention and Reputation Incentives for Outside Directors", The Journal of Finance, vol. LIX(5): 2281-308. 